\title{
Klęska państwa czechosłowackiego w 1938 roku
}

Zarys treści: W artykule omówione zostały przyczyny geopolitycznej klęski Czechosłowacji, które doprowadziły w 1938 r. do aneksji części jej terytorium przez Trzecią Rzeszę przy całkowicie biernej postawie Europy Zachodniej. Autor wskazuje błędy popełnione przez prezydenta Czechosłowacji Edwarda Beneša zarówno na polu militarnym (zignorowanie niebezpieczeństwa ze strony Niemiec), jak i międzynarodowym (niechęć do jakiegokolwiek współdziałania z Polską).

Outline of content: The article portrays the causes of Czechoslovakia's geopolitical crisis, which led the Third Reich to annex a part of the country's territory in 1938 with no opposition whatsoever from the Western powers. The author points out the errors committed by Czechoslovak President Edvard Beneš in both the military field (by disregarding the German threat) and his foreign policies (by refusing to cooperate with Poland).

Słowa kluczowe: Edward Beneš, polityka czechosłowacka 1938, stosunki polsko-czechosłowackie, aneksja Czechosłowacji, konferencja w Monachium

Keywords: Edvard Beneš, Czechoslovak policy 1938, Polish-Czechoslovak relations, the annexation of Czechoslovakia, Munich Conference on Security Policy

Odpowiedzialność Beneša za klęskę państwa czechosłowackiego w 1938 r. nie ulega żadnej wątpliwości. Beneš popełnił dwa podstawowe błędy, które dyskwalifikowały go jako poważnego polityka, za którego pragnął uchodzić. Po pierwsze zignorował rady czechosłowackich wojskowych, poważnie traktujących niebezpieczeństwo grożące ze strony Niemiec Hitlera. Po drugie nie dopuścił do sojuszu z Polską. Jego nienawiść do państwa polskiego, datująca się od schyłku pierwszej wojny światowej, odegrała niebagatelną rolę w okresie międzywojennym. Zresztą w kategoriach racjonalnych trudno było nastawienie Beneša do Polski wyjaśnić. Oba państwa, Polska i Czechosłowacja, potrzebowały sojusznika, żeby przetrwać. Okazało się jednak, że ta zdawałoby się prosta prawda nie była w stanie dotrzeć do świadomości czechosłowackich polityków. Tragedia drugiej wojny światowej, która później się rozegrała, a która przede wszystkim dotknęła Polskę, sprawiła, że zapłaciła ona 
najwyższą cenę i jako potencjalny sojusznik przestała się liczyć. Nad Polską i Czechosłowacją rozciągnął protektorat Związek Sowiecki. Beneš w swojej naiwności liczył na wsparcie Sowietów w chwili zagrożenia ze strony Niemiec. Udowadniał w ten sposób, że zupełnie nie rozumiał, czym był Związek Sowiecki i czego można było od niego oczekiwać.

Zaczęło się jednak od Anschlussu Austrii, czyli wcielenia tego państwa do Rzeszy niemieckiej. Formalnie nastąpiło to 13 marca 1938 r., faktycznie zaś proces zajmowania Austrii rozpoczął się nieco wcześniej. Już w nocy z 11 na 12 marca 1938 r. marszałek Rzeszy Herman Goering powiadomił posła czechosłowackiego w Berlinie Vojtěcha Mastnego o przeprowadzanym właśnie Anschlussie, zapewniając jednocześnie pod słowem honoru, że Niemcy nie mają wobec Czechosłowacji wrogich zamiarów, a wprost przeciwnie, obecnie po przeprowadzeniu Auschlussu mają nadzieję na polepszenie stosunku do Czechosłowacji pod warunkiem, że w Czechosłowacji nie będzie przeprowadzona mobilizacja. Mastny obliczył, że Goering w ciągu trzech dni dał mu czterokrotnie słowo honoru, w tym również raz w imieniu Hitlera. Natomiast czechosłowacki minister spraw zagranicznych Kamil Krofta pospieszył wobec posła niemieckiego w Pradze Ernsta Eisenlohra z oświadczeniem, że Czechosłowacja nie mobilizuje swoich sił wojskowych. Część prasy niemieckiej rozpowszechniała bowiem pogłoski na temat mobilizacji wojsk czechosłowackich. 13 marca 1938 r. poseł polski w Pradze Kazimierz Papée usłyszał z ust ministra Krofty, że „jeśli cały świat nas opuszcza, będziemy zapewne musieli z czasem ulec [presji] i wejść, nolens volens w orbitę wpływów III Rzeszy”. Trudno wszakże pominąć fakt, że państwo czechosłowackie było tworem niedoskonałym, a przez to nietrwałym, w którym drugim w kolejności narodem zamieszkującym byli Niemcy. Można się było spodziewać, iż prędzej czy później władze czeskie w Pradze będą zmuszone liczyć się z aspiracjami tzw. Niemców sudeckich, które z czasem będą stawały się coraz bardziej zdecydowane, jednocześnie zagrażając integralności republiki czechosłowackiej. Ciesząca się popularnością wśród ludności niemieckiej Partia Niemców Sudeckich mogła przy wsparciu Rzeszy niemieckiej odegrać rolę czynnika rozsadzającego Czechosłowację ${ }^{1}$.

Pozycja armii czechosłowackiej w republice nie należała do najsłabszych. Generalicja zaś obarczała odpowiedzialnością za brak woli zbrojnego przeciwstawienia się ewentualnej agresji ze strony Trzeciej Rzeszy rządzącą Czechosłowacją tzw. grupę Hradu z Benešem na czele. Nie miał on rzeczywiście zamiaru przyjmować rozwiązań preferowanych przez wojskowych. Ich sojusznikiem była natomiast partia agrarna o charakterze prawicowym. W raporcie z 2 kwietnia 1938 r. poseł Papée donosił, że w praskich kołach politycznych rozeszła się pogłoska, że „pewne koła prawicowe przy poparciu grupy generałów przygotowywały zamach stanu z zamiarem usunię-

1 K. Schuschnigg, W zmaganiu z Hitlerem. Przezwyciężenie idei Anschlussu, Kraków 1978, s. 12-13; V. Mastný, Vzpomínky diplomata, Ze vzpominek a dokumenti̊ československého vyslance, Praha 1997, s. 78-79; Z. Landau, J. Tomaszewski, Monachium 1938, Polskie dokumenty dyplomatyczne, Warszawa 1985, s. 47-49, 62 . 
cia Beneša i że w związku z tym generałowie Vojcechovský i Fischer zostali aresztowani”. „Pogłoska ta - raportował poseł - okazała się w szczegółach nieprawdziwą”. Dodawał, że „jest ona charakterystycznym objawem niepewności oraz zdenerwowania, jakie ogarnęło pewne sfery, oraz dowodem coraz większego niezadowolenia z polityki prezydenta Beneša”. Wspomniani dwaj generałowie „zażądali od rządu natychmiast po Anschlussie, by wprowadzony został w myśl ustawy o obronie państwa stan pogotowia wojennego tj. częściowa mobilizacja, rozdanie broni i zaostrzenie przepisów bezpieczeństwa w powiatach nadgranicznych” zamieszkałych przez ludność niemiecką. W związku z tym „doszło do gwałtownej wymiany zdań między nimi a rządem, który sprzeciwił się jawnemu wprowadzeniu w życie tych przepisów, a zgodził się jedynie na rozdanie po cichu broni organizacjom czeskim". Gen. Vojcechovskiego poseł Papée uznawał za „nastrojonego wybitnie propolsko”2.

Wkrótce jednak 4 kwietnia 1938 r. poseł polski w Pradze wysłał do centrali kolejną informację, że „w związku z sytuacją międzynarodową spowodowaną Anschlussem rząd tutejszy poczynił obszerne zarządzenia natury wojskowej”, choć „mobilizacji nie ogłoszono i wszystkie zarządzenia rząd stara się utrzymać w tajemnicy tak, że nie doszło do opublikowania stanu pogotowia wojennego w myśl ustawy o obronie państwa, gdyż obawiano się reakcji międzynarodowej na taki krok”. Papée donosił, że „na całym pograniczu wprowadzono de facto stan pogotowia w garnizonach i umocnieniach granicznych, niektóre oddziały z centrum kraju przesunięto w kierunku granicy, zmobilizowano C. P. O. (cywilną obronę przeciwlotniczą) i rozdano broń organizacjom przysposobienia wojennego i bojówkom czeskich partii koalicyjnych". Najwidoczniej generałowie czescy potrafili przynajmniej częściowo przeforsować swój punkt widzenia. Tzw. grupa Hradu najbardziej obawiała się, że przygotowania wojenne w razie ich ujawnienia byłyby „ze względów politycznych niewygodne i niebezpieczne dla polityki zagranicznej”. Poseł polski w Pradze informował centralę 13 kwietnia 1938 r., że „to ukryte pogotowie wykazało dużą sprawność armii i zostało szybko i bez przeszkód przeprowadzone”, zaś „duch armii okazał się dobry” mimo „często burzliwych dyskusji w korpusie oficerskim”. Polski dyplomata dodawał, że „nie zauważono w armii nastrojów defetystycznych”. Według niego „armia czechosłowacka okazała się odporniejsza nerwowo od polityków, którzy w pierwszej chwili [w czasie dokonywania Anschlussu] potracili głowy, gdy tymczasem dowództwo zajęło się przeprowadzaniem pewnych bezpośrednich środków ostrożności, ale ani nie zostało ogarnięte paniką, ani nie posunęło się do poczynienia pewnych nierozważnych kroków, mogących sytuację zaostrzyć”3.

Tymczasem sfery polityczne Czechosłowacji przypomniały sobie, że można by spróbować szukać pomocy w Polsce. Papée informował centralę 23 kwietnia 1938 r., że poseł czechosłowacki w Warszawie Juraj Slávik „otrzymał wczoraj od Beneša polecenie przygotowania próby porozumienia z Warszawą”. W dniach zaś między 6 a 13 kwietnia 1938 r. bawił w Polsce z tygodniową wizytą dziennikarz Vaclav

2 Ibidem, s. 70-71.

3 Ibidem, s. 76, 85. 
Fiala, wysłany do Warszawy przez ministra Kroftę. Spotkał się z szeregiem przede wszystkim opozycyjnych polskich polityków, niechętnych władzom Rzeczypospolitej. Na tej podstawie wyrobił sobie opinię, która nie była korzystna dla idei zbliżenia Polski z Czechosłowacją. Tym niemniej 25 kwietnia 1938 r. do Polski zawitał drugi czeski dziennikarz, redaktor polityczny organu agrariuszy „Venkova” Ferdinand Kahánek, nastawiony podobnie jak partia, którą reprezentował, życzliwie do Polski. Oświadczył radcy w wydziale prasowym polskiego MSZ Zbigniewowi Łasińskiemu, że w „ostatnich dniach prezydent Beneš zajęty jest analizowaniem stosunku ČSR do Polski i że, jak mu jest wiadomo, nie tylko ze sfer jego partii, produktem tej analizy będzie propozycja, która zostanie w najbliższym czasie (dniach) złożona w Warszawie”. Kahánek zapewnił Łasińskiego, „iż jego stronnictwo nigdy nie podzielało poglądów Hradu na sytuację i że stało i stoi na stanowisku, iż rozmowy z Warszawą powinny poprzedzić nieuniknione rozmowy z Berlinem” i „tylko też wtedy mogą one mieć swą wartość". Kahánek uważał, że odpowiednim wyjściem z zaistniałej sytuacji, w jakiej znalazła się Czechosłowacja, byłoby związanie się z Polską w formie sojuszu wojskowego i unii celnej. Zdaniem czeskiego dziennikarza „Czesi dobrze zdają sobie sprawę z bezużyteczności paktu łączącego ich z Sowietami”"

O ile postawa Kahánka mogła świadczyć o dobrej woli strony czechosłowackiej, o tyle takiego wniosku nie można było wyciągnąć z wypowiedzi posła czechosłowackiego w Polsce Juraja Slavika, szefa dyplomatycznego protokołu kancelarii prezydenta republiki Jaromira Smutnego oraz samego prezydenta Beneša. W dniu „11 kwietnia 1938 r. prezydent czechosłowacki oświadczył Slávikowi, że ma zamiar uczynić jeszcze jedną próbę porozumienia z Polską i prosił posła, aby przygotował zwięzłą propozycję, jak w obecnej sytuacji postępować". Jednocześnie wyjaśniał, że „owa próba ma być zarówno dowodem dla naszych sojuszników (Francji, Rumunii) i Anglii, że z naszej strony nie brakuje dobrej woli do porozumienia z Polską, jak i argumentem przeciwko tym u nas w kraju, którzy wytykają naszej polityce zagranicznej, że nie potrafi doprowadzić do porozumienia przynajmniej ze słowiańskim sąsiadem, z Polską". Beneš uważał, że przed porozumieniem z Polską powinna być najpierw polepszona atmosfera między obu państwami. Slávik utrzymywał jednak, że dopóki „nie ulegnie zmianie w Polsce reżim i dopóki Beck będzie kierować polską polityką zagraniczną, nie ma najmniejszej nadziei ani na czechosłowacko-polskie porozumienie, ani na szczery sojusz [Polski] z Francją, ani na odejście Polski od służenia niemieckim interesom". Coś podobnego mogli wymyślić tylko czescy politycy wrogo do Polski nastawieni. Strona polska nie służyła niemieckim interesom, natomiast czeska swego czasu poważnie zabiegała o możliwość bliskiej współpracy z Niemcami. Tyle tylko, że Niemcy odrzuciły wówczas czeską ofertę. Smutný natomiast głosił, że w sprawie Śląska Zaolziańskiego, który władze polskie pragnęły odzyskać, „Polsce chodzi o rewanż, ponieważ w sercu każdego Polaka tkwi mściwość". Podobne tłumaczenie nie mogło być traktowane poważnie. Tym niemniej

4 Ibidem, s. 89-90; Dokumenty československé zahraniční politiky. Československá zahraniční politika v roce 1938 (dalej: ČZP 1938) t. I, leden-30 červen 1938, Praha 2000, s. 345. 
należało do arsenału czeskiego słownictwa propagandowego. Nawiasem mówiąc Smutný był bardziej radykalnie antypolski od Slávika 5 .

W memorandum z 20 kwietnia 1938 r. przygotowanym przez Slávika dla Beneša znalazły się stwierdzenia dowodzące braku dobrej woli ze strony czeskiej oraz świadczące o tym, że ludzie Beneša nie traktowali poważnie możliwości porozumienia ze stroną polską. Slávik głosił, że próba porozumienia wprawdzie powinna mieć miejsce, ale nie powinna wzmacniać reżimu w Polsce, który - jego zdaniem - jest wrogi wobec Czechosłowacji. Według niego, co brzmiało demagogicznie, próba porozumienia „musi być próbą porozumienia z polskim narodem, nie zaś z polskim reżimem". Ewidentnie grupa Hradu ośmielała się ingerować w wewnętrzne sprawy państwa polskiego. Stawiało to pod znakiem zapytania możliwość autentycznego sojuszu Czechosłowacji z Polską. Zresztą stronie czeskiej nie zależało na rzeczywistym porozumieniu, gdyż uprawiała grę pozorów. Udawała, że zależy jej na zbliżeniu z Polską, gdy tymczasem pragnęła wygrywać kartę polską dla swoich celów niemających nic wspólnego $\mathrm{z}$ autentycznym zaangażowaniem $\mathrm{w}$ proces budowania sojuszu Czechosłowacji z Polską. Nawiasem mówiąc ów proces wymagał, gdyby go poważnie potraktować, sporo czasu. Tymczasem Slávik proponował Benešowi, aby ograniczyć do trzech miesięcy czas działania na rzecz porozumienia na polach gospodarczym, kulturalnym, sportu i politycznym. Uważał, że należałoby skłonić stronę polską do najściślejszej współpracy policyjnej, mającej na celu zapobieganie komunistycznej propagandzie i jej przenoszeniu do Polski. Nawiasem mówiąc poseł polski w Pradze złożył 22 marca 1938 r. czechosłowackiemu ministrowi spraw zagranicznych Krofcie notę w sprawie antypolskiej działalności Kominternu na terenie Czechosłowacji. Funkcjonariusze Kominternu korzystali bowiem z gościny w Czechosłowacji nie niepokojeni przez miejscowe władze. Slávik proponował też po upływie trzech miesięcy spowodowanie akcji pośredniczenia między Francją lub Wielką Brytanią a Polską by dowiedzieć się od rządu polskiego jakie stawia warunki porozumienia z Czechosłowacją. W ten sposób - pisał Slávik - można by podkreślić, że zachodnim mocarstwom zależy na porozumieniu dwóch sąsiednich państw i dwóch sojuszników Francji, a polska propaganda nie mogłaby tego faktu potraktować jako oznaki słabości ${ }^{6}$.

W raporcie z 28 maja 1938 r. poseł Papée informował centralę, że „W nocy z dnia 20 na 21 maja zarządzono w Czechosłowacji częściową mobilizację oraz obsadzono wojskowe granice republiki, przede wszystkim granicę czechosłowacko-niemiecką". Poseł polski informował władze Rzeczypospolitej, że pograniczne prowincje czeskie zamieszkałe przez ludność niemiecką „znalazły się pod [czechosłowacką] okupacją wojskową”. Papée tłumaczył „krok rządu czechosłowackiego przede wszystkim rzekomą koncentracją wojsk niemieckich na

5 Ibidem, s. 341-346.

6 Ibidem, s. 342-346; Warszawska filia Antykominternu. Nieopublikowane dokumenty MSZ Polski w sprawie tzw. Ekspozytury Kominternu w Pradze, [w:] Studia z Najnowszych Dziejów Powszechnych, t. 3, PWN, Warszawa 1963, s. 241-298; Polskie dokumenty dyplomatyczne 1938, Warszawa 2007, s. 171-172. 
granicy oraz koniecznością opanowania sytuacji politycznej w Sudetach, gdzie zajścia przybierały coraz większe rozmiary”. Postawa czechosłowackich kół wojskowych przyniosła pozytywne rezultaty, gdyż „na skutek zarządzeń czeskich, koncentracja wojsk niemieckich została przerwana i cofnięta", a od tygodnia żadnych zajść nie było i autorytet władzy czechosłowackiej został przywrócony. Papée relacjonował też opinię posła niemieckiego w Pradze Ernsta Eisenlohra, który twierdził, że mobilizacja w Czechosłowacji „jest jego zdaniem pewnego rodzaju zamachem stanu sfer wojskowych i Beneša przede wszystkim w celach wewnętrznopolitycznych”. Czechosłowacki „Sztab Generalny żądał pierwotnie powołania pod broń pięciu roczników i że rząd się na to nie zgodził”. Papée donosił do polskiego MSZ, że „wydaje się nie ulegać wątpliwości, że koncentracji wojsk niemieckich na granicach czeskich nie było”, natomiast „pierwszy alarm na temat koncentracji wojsk niemieckich wyszedł od attaché wojskowego ambasady angielskiej w Berlinie”. „Jeśli chodzi o sytuację wewnętrzną - depeszował polski poseł w Pradze - mobilizacja dała bezsprzecznie z punktu widzenia czeskiego dodatnie rezultaty”, gdyż „ustały zajścia na pograniczu i autorytet władzy został przywrócony” zaś „sama mobilizacja i wszystkie zarządzenia wykazały dużą sprawność wojska”. „Nastrojowo - donosił Papée - władze musiały raczej hamować zbytni zapał bojowy opinii czeskiej”. „Cała opinia bez wyjątku - pisał polski poseł - zsolidaryzowała się z zarządzeniami wojskowymi i ludność czeska chętnie pomagała w ich wykonywaniu"7.

We wspomnianym raporcie z 28 maja 1938 r. Papée przypominał, że czechosłowackie „koła wojskowe już od dawna napierały na rząd w kierunku stosowania polityki silnej ręki oraz nieustępliwości, idąc nawet do pewnego stopnia na ryzyko wojny". Koła te uzyskawszy poparcie Beneša wydały zarządzenia, które według największego prawdopodobieństwa rząd [czechosłowacki] zaaprobował, post factum - twierdził polski poseł. Poseł czechosłowacki w Niemczech Vojtěch Mastný uważał, że „dni między 20 a 23 maja 1938 r. były dniami trudnego egzaminu dla Czechosłowacji, której zagroziło niebezpieczeństwo bezpośredniego wybuchu wojny". Twierdzenie to było raczej pozbawione w tym czasie podstaw, choć atmosfera nerwowości mogła się udzielać nawet najlepiej poinformowanym politykom. W interwencje u czynników niemieckich zaangażował się brytyjski ambasador w Niemczech Neville Henderson, który w dniach od 20 do 22 maja 1938 r. czterokrotnie odbywał rozmowy z niemieckim sekretarzem stanu w MSZ Ernstem von Weizsäckerem i dwukrotnie z niemieckim ministrem spraw zagranicznych Joachimem von Ribbentropem, pragnąc zapobiec wymknięciu się wydarzeń spod kontroli. W dniu 20 maja 1938 r. Ribbentrop oświadczył Mastnemu, że strona niemiecka nie może ścierpieć, aby przez rząd czechosłowacki były przekazywane „innym rządom nieprawdziwe informacje o wojskowych koncentracjach sił zbrojnych Niemiec i zwraca uwagę z naciskiem, że szerzenie takich informacji mogłoby prowadzić do ich spełnienia i do rzeczywistej koncentracji sił zbrojnych przeciw Czechosłowacji”. W dniu 16 czerwca 1938 r.,

7 Z. Landau, J. Tomaszewski, op. cit., s. 153-157. 
a więc około miesiąc później, po powrocie z Berlina korespondent Reutera „poufnie poinformował, że Henderson mu wyraźnie powiedział, iż jego ostatnia interwencja okazała się wielkim blamażem, ponieważ informacja, którą otrzymał od [władz czechosłowackich] o ruchach wojsk niemieckich okazała się nieprawdziwa", gdyż przesunięć wojsk niemieckich, jak stwierdził to attache brytyjski, nie było ${ }^{8}$.

Pozycja państwa czechosłowackiego na arenie międzynarodowej coraz bardziej słabła. Przywódca partii Niemców sudeckich Konrad Henlein, polityk dyspozycyjny wobec Hitlera, już 24 kwietnia 1938 r. wystąpił na zjeździe tej partii w Karlových Varach z ośmiopunktowym programem, zawierającym postulaty wobec władz czeskich. Najważniejszym żądaniem było wprowadzenie na obszarach państwa czechosłowackiego zamieszkałych przez ludność niemiecką autonomii (Selbstverwaltung). Program Henleina, zwany programem karlsbadzkim, został przez Beneša uznany za niebezpieczny dla integralności terytorialnej Republiki Czechosłowackiej. 12 września 1938 r. Hitler na zjeździe partii nazistowskiej w Norymberdze wygłosił mowę, w której po raz pierwszy w imieniu Rzeszy oficjalnie ogłosił się protektorem Niemców sudeckich i zażądał dla nich prawa do samostanowienia. Kryzys wkroczył w decydującą fazę, tym bardziej że władze w Pradze zdecydowały się na wprowadzenie 13 września 1938 r. stanu wyjątkowego, wysyłając do niektórych powiatów zamieszkałych przez ludność niemiecką wojsko i dodatkowe posiłki żandarmerii. Miasteczko Aš w północno-zachodnich Czechach wraz z okolicą zostało oderwane od państwa czechosłowackiego. Na ten obszar przeniosło się kierownictwo partii Niemców sudeckich: „Niemcy w Czechosłowacji nie są ani bezbronni ani opuszczeni” grzmiał Hitler, strasząc również swoich rodaków wizją wojny ${ }^{9}$.

Według tłumacza Hitlera Paula Schmidta „rano 14 września nastąpił dramatyczny i sensacyjny zwrot. Stanowił go tekst zawierający 7 linijek, które miałem przetłumaczyć Hitlerowi”. Brytyjski premier Neville Chamberlein proponował wodzowi Trzeciej Rzeszy, z uwagi na coraz bardziej krytyczną sytuację wokół nierozstrzygniętej kwestii Niemców sudeckich, swoje natychmiastowe przybycie do Hitlera „W celu znalezienia pokojowego rozwiązania”. Tym sposobem sprawa Niemców sudeckich urastała do rangi problemu międzynarodowego, który miałby stać się przedmiotem podejmowania decyzji przez mocarstwa bez udziału władz czechosłowackich. Ponadto brytyjski premier, wysyłając list do Hitlera, sam dobrowolnie stawiał się w roli petenta zabiegającego o względy obcego mu ideowo i agresywnego mocarstwa, zagrażającego pokojowi światowemu. Dnia 23 września 1938 r. została ogłoszona w Czechosłowacji „druga i bardziej rozległa mobilizacja” sił zbrojnych. Nie spodobała się ona stronom brytyjskiej i francuskiej. Zdaniem parlamentarnego

8 Ibidem, s. 153-157; V. Mastný, op. cit., s. 99-145; ČZP 1938, t. I, s. 456-463, 537; N. Henderson, Nieudana misja Berlin 1937-1939, Warszawa 1970, s. 97-104; P. Schmidt, Statysta na dyplomatycznej scenie, Kraków 1962, s. 384-386.

9 P. M. Majewski, Edvard Beneš i kwestia niemiecka w Czechach, Warszawa 2001, s. 134; H. Masařík, V proměnach Evropy. Paměti československeho díplomata, Praha 2002, s. 213; E. Beneš, Mnichovské dny, Paměti, Praha 1968, s. 36-38; P. Schmidt, op. cit., s. 387-388; N. von Below, Bytem adiutantem Hitlera 1937-45, Warszawa 1990, s. 116-117. 
sprawozdawcy ministra spraw zagranicznych Kamila Krofty, Huberta Masařika, „mobilizacja 44 dywizji wypadła dobrze, co musieli uznać również wrogowie Czechosłowacji, jak na przykład ówczesny rząd polski”. Masařik bezpodstawnie nazwał władze Rzeczypospolitej wrogimi tylko dlatego, że te dążyły do odebrania Czechosłowacji ziem polskich Śląska Cieszyńskiego, zagrabionych przez wojska czeskie w styczniu 1919 roku $^{10}$.

Polityka władz francuskich wobec rządu polskiego świadczyła o tym, że strona francuska nie pragnęła angażować się w obronę Czechosłowacji zagrożonej przez Rzeszę niemiecką mimo obowiązującego czechosłowacko-francuskiego sojuszu. Chętnie natomiast była gotowa wysługiwać się innymi państwami, które nie miały odpowiednich zobowiązań wobec Republiki Czechosłowackiej. Trzeba przyznać, że postawa rządu francuskiego musiała budzić zrozumiałą niechęć rządu polskiego, który dobrze orientował się w istocie gry uprawianej przez czynniki francuskie. Punkt kulminacyjny francuscy sojusznicy Polski osiągnęli w połowie lipca 1938 roku. W dniu 16 lipca 1938 r. ambasador francuski w Polsce Leon Noël zapytał polskiego ministra spraw zagranicznych Józefa Becka „co właściwie nam [tzn. stronie polskiej] szkodzi stwierdzić na piśmie, że nie zaatakujemy Czechosłowacji”. Beck wykazując się szybkim refleksem oświadczył, że "takie pytanie stawia go w pozycji gentlemana, od którego żądają, aby stwierdził na piśmie, że nie oszukuje w karty”. Odpowiedź Becka była tym bardziej trafna, że poseł czechosłowacki w Paryżu Štefan Osuský w telegramie z 29 czerwca 1938 r. informował swoją centralę, że „17 czerwca 1938 r. polski ambasador we Francji [Juliusz] Łukasiewicz stanowczo oświadczył francuskiemu ministrowi spraw zagranicznych [Georgowi] Bounetowi, że w żadnym wypadku Polska nie napadłaby na Czechosłowację". Wszelkie więc spekulacje co do wrogiej postawy Polski wobec Republiki Czechosłowackiej były pozbawione jakichkolwiek podstaw ${ }^{11}$.

Interesujące było natomiast to, w jaki sposób Beneš zamierzał postąpić w obliczu ewidentnego mieszania się Francji i Wielkiej Brytanii w wewnętrzne sprawy Czechosłowacji. Otóż wymyślił on plan, powierzając jego wykonanie prawicowemu socjaldemokracie, czechosłowackiemu ministrowi opieki społecznej Jaromirowi Nečasowi. W dniu 15 września 1938 r. Beneš przesłał Nečasowi tajne wytyczne do pertraktacji z francuskimi i angielskimi prawicowymi socjalistami. Deklarował w tym dokumencie gotowość do odstąpienia Rzeszy niemieckiej terenów pogranicznych z Czechosłowacją. Beneš pouczał Nečasa, że nie można dopuścić do tego, by ktoś „mógł powiedzieć, że plan został wysunięty przez Czechosłowację”. „Wymagana jest całkowita tajność, nie wolno niczego publikować" - nakazywał prezydent czechosłowackiemu ministrowi. Uważał, że „plan musiałby być ustalony tajnie przez Francję

10 H. Masařík, op. cit., s. 239-240; P. Schmidt, op. cit., s. 388; ČZP 1938, t. II, s. 372-374; M. K. Kamiński, Konflikt polsko-czeski 1918-1921, Warszawa 2001.

11 M. J. Zacharias, Sytuacja międzynarodowa i polityka zagraniczna Polski w latach 1936-1939 (w związku z publikacją materiałów Juliusza Łukasiewicza pt. Dyplomata w Paryżu 1936-1939, pod red. W. Jędrzejewicza i H. Bułhaka), „Kwartalnik Historyczny”, R. CIV, Warszawa 1997, s. 47-48; ČZP 1938, t. I, s. 587-588, 209-210. 
i Anglię po naszym uprzednim oznaczeniu obszarów, które moglibyśmy odstąpić [...] oznaczałoby to, że Niemcy otrzymaliby tyle a tyle $\mathrm{km}^{2}$ naszego terytorium, sam nie wiem, ale wynosiłoby to prawdopodobnie od 4 do 6 tys. $\mathrm{km}^{2}$ naszego terytorium, ale nie trzeba się w tej sprawie wiązać pod warunkiem, żeby od nas zabrali 1,5 do 2 mln niemieckich mieszkańców, przy czym demokraci, socjaliści i Żydzi zostaliby u nas”. Zdaniem Beneša „plebiscyt jest po prostu niemożliwością z punktu widzenia technicznego, prawnego i politycznego". Prezydent Czechosłowacji nakazywał Nečasowi, by nic nie „mówić, że plan pochodzi ode mnie [od Beneša]” oraz aby „nic nie mówić [Štefanowi] Osuskiemu [posłowi czechosłowackiemu w Paryżu] i „zniszczyć niniejszy dokument”, będący kompromitacją Beneša, z czego ten zdawał sobie doskonale sprawę. Dokument ten nie został jednak wbrew woli Beneša zniszczony, co oznaczało, że prędzej czy później ujrzy światło dzienne, a prezydent Czechosłowacji nie uniknie surowej oceny politycznej. W dniu 20 września $1938 \mathrm{r}$. Beneš i premier Milan Hodża wyrazili gotowość przyjęcia projektu angielsko-francuskiego co do odstąpienia terenów pogranicznych Niemcom, ale ze względów wewnętrznopolitycznych domagali się, aby projekty te były przyjęte $\mathrm{w}$ formie ultymatywnej. Chcieli wywołać wrażenie, że zostali zmuszeni do ustępstw terytorialnych pod zewnętrznym naciskiem i z tego względu nie będą w przyszłości ponosić odpowiedzialności za fatalne kierowanie krajem, które doprowadziło do załamania się i klęski państwa czechosłowackiego ${ }^{12}$.

Tymczasem wojskowi czechosłowaccy liczyli się z możliwością zbrojnej konfrontacji w obliczu agresywnych zamiarów Trzeciej Rzeszy. Gen. Sergej Ingr zgłosił w imieniu wyższych dowódców gotowość do zbrojnego przeciwstawienia się agresywnym poczynaniom Rzeszy niemieckiej. Beneš jednak nakazał aresztowanie generała, byle nie dopuścić do sytuacji grożącej wybuchem działań wojennych. Również gen. Ludvik Krejčí, szef sztabu armii czechosłowackiej był zdania, że Czechosłowacja jest w stanie oprzeć się agresji niemieckiej. Zwracał też uwagę, że zgodnie z konstytucją bez zgody parlamentu żaden rząd czechosłowacki nie ma prawa rezygnować z części terytorium swego państwa. Zdaniem gen. Krejčego siły czechosłowackie i niemieckie były wyrównane, przy czym ważnym atutem strony czechosłowackiej były trudne do sforsowania fortyfikacje. Uważał, że nie można pozwolić, by zostały one przekroczone przez siły zbrojne innego państwa. „Nie dotyczy to Polski” - mówił gen. Krejčí premierowi gen. Janowi Syrowemu. Propolskie nastroje utrzymywały się w czechosłowackim korpusie oficerskim. Niestety czechosłowaccy wojskowi niewiele mieli do powiedzenia w sprawach politycznych. Beneš zadbał o to, by nie dopuścić wojskowych do współdecydowania o losie republiki czechosłowackiej. „Nie jesteśmy Abisynią - mówił gen. Krejčí - stoimy tu z silną armią, która jest w stanie wytrzymać niemieckie uderzenie”. Strona czechosłowacka posiadała 1700 samolotów i cztery dywizje pancerne, podczas gdy Niemcy dysponowały wówczas

12 Mnichov v dokumentech, t. II, zrada česke a slovenske burzuasie na československem lidu, Praha 1958; T. Borowy (Oswald Guziur), Beneš a Monachium, „Przegląd Tygodniowy”, 8 I 1989; F. Bajorek, Sprawa Zaolzia w okresie kryzysu, „Tydzień Polski”, 20 XII 1980. 
3000 samolotów i pięcioma dywizjami pancernymi. Armia czechosłowacka po przeprowadzeniu 23 września 1938 r. powszechnej mobilizacji liczyła 45 dywizji, podczas gdy Niemcy miały 47 dywizji w stanie bojowym. Cywilna ekipa rządząca Czechosłowacją z Benešem na czele nie miała woli walki, co przyczyniło się do upadku państwa czechosłowackiego w 1938 roku $^{13}$.

W dniu 19 września 1938 r. posłowie Wielkiej Brytanii w Czechosłowacji Basil Newton i Francji w Czechosłowacji Victor Lacroix rozpatrzyli sprawozdanie Nevilla Chamberlaina z rozmów z Hitlerem. Obie strony, brytyjska i francuska, doszły do wniosku, że „dalsze utrzymywanie w granicach państwa czechosłowackiego okręgów zamieszkałych głównie przez Niemców sudeckich faktycznie nie może trwać nadal bez zagrożenia interesów samej Czechosłowacji i pokoju europejskiego". W memorandum francusko-brytyjskim znalazło się stwierdzenie, że „oba rządy zostały zmuszone dojść do wniosku, że zachowanie pokoju oraz bezpieczeństwa żywotnych interesów Czechosłowacji nie może być skutecznie zapewnione, jeśli obszary te nie zostaną obecnie przekazane Rzeszy”. Rząd czechosłowacki nie omieszkał zwrócić uwagi, że mocarstwa podjęły decyzje „bez zapytania przedstawicieli Czechosłowacji, przeciw której podjęto działanie bez jej wysłuchania, chociaż Rząd Czechosłowacki zwracał uwagę, że nie może przyjąć odpowiedzialności za oświadczenie złożone poza nim”. Według konstytucji czechosłowackiej z 29 lutego 1920 r., art. 3 ust. 1, granice państwa mogły ulec zmianie tylko w wyniku ustawy uchwalonej przez obie izby parlamentu większością kwalifikowaną. Rząd czechosłowacki zastrzegał się, że nie może z powodów konstytucyjnych podjąć decyzji dotyczących granic, gdyż „taka decyzja nie byłaby możliwa bez naruszenia ustroju demokratycznego i porządku prawnego państwa czechosłowackiego". „W każdym wypadku - brzmiało oświadczenie czynników czechosłowackich należałoby zasięgnąć zdania parlamentu". Władze czechosłowackie uderzyły też w błagalny ton zwracając się „,z ostatnim apelem” i prośbą do mocarstw zachodnich, by „pogląd swój poddały rewizji”, czyli wycofały się z zamiaru okrojenia państwa czechosłowackiego $\mathrm{w}$ imię zachowania pokoju ${ }^{14}$.

Reakcje brytyjsko-francuskie nie kazały długo na siebie czekać. W dniu 21 września 1938 r. mocarstwa zachodnie oświadczały, że ich zdaniem stanowisko zajęte przez rząd czechosłowacki „bynajmniej nie odpowiada krytycznej sytuacji, której zamierzały zapobiec propozycje anglo-francuskie”. „Gdyby Rząd Czechosłowacki obstawał przy tej [swojej] odpowiedzi - [z 20 września 1938 r.] głosili przedstawiciele mocarstw zachodnich i - opublikował ją, wywołałoby to natychmiastową inwazję niemiecką". Wielka Brytania i Francja posunęły się więc do szantażu i straszenia Czechosłowacji konsekwencjami militarnymi w wypadku niepodporządkowania się ich woli. Mocarstwa zachodnie „zaproponowały” wycofanie czechosłowackiej

13 T. Borowy (Oswald Guziur), op. cit.

14 H. Batowski, Rok 1938 - dwie agresje hitlerowskie, Poznań 1985, s. 463-464, 466-469; ČZP 1938, t. II, s. 321-326, 343-347, 359-360; Współczesna Europa polityczna. Zbiór umów międzynarodowych 1919-1939, oprac. W. Kulski, M. Potulicki, Warszawa-Kraków, 1939, s. 403. 
odpowiedzi z 20 września 1938 r. i „jak najszybsze rozważenie innej, która liczyłaby się z istniejącą sytuacją". Rząd czechosłowacki powoływał się na czechosłowackoniemiecki traktat arbitrażowy, wchodzący w skład układów lokarneńskich parafowanych w Lokarno 16 października 1925 r. oraz podpisanych 1 grudnia 1925 r. w Londynie. Przypomniał, że traktat arbitrażowy „w kilku oświadczeniach obecny Rząd Niemiecki uznał za nadal obowiązujący”. Rząd czechosłowacki stwierdzał zatem, że „traktat ten można zastosować i domagał się, aby tak się stało”, natomiast „respektując swój podpis, gotów jest poddać się każdemu wyrokowi rozjemczemu, który by zapadł”. „W ten sposób - twierdziła strona czechosłowacka - przeszkodziłoby się jakiemukolwiek sporowi”, co „umożliwiłoby rozwiązanie szybkie, honorowe, godne wszystkich uczestników". Hitlerowi tymczasem nie zależało na żadnym rozjemstwie. Pragnął jedynie wymusić na Czechosłowacji ustępstwa terytorialne, korzystając ze wsparcia mocarstw zachodnich, które ze strachu przed Hitlerem gotowe były poświęcić Republikę Czechosłowacką i opowiedzieć się po stronie agresywnej Trzeciej Rzeszy. W dniu 21 września 1938 r. rząd czechosłowacki „pod niezwykle silnym naciskiem” ze strony mocarstw zachodnich, „, żalem przyjął propozycje francuską i brytyjską, zakładając, że oba rządy uczynią wszystko, by przy realizowaniu propozycji chronione były żywotne interesy państwa czechosłowackiego". Władze czechosłowackie stwierdzały „z ubolewaniem, że propozycje te zostały opracowane bez uprzedniego zapytania o zdanie Rządu Czechosłowackiego". Władze czechosłowackie „żałowały też głęboko, że ich projekt arbitrażu nie został przyjęty” przez mocarstwa zachodnie ${ }^{15}$.

Hitler tymczasem uciekał się do pogróżek pod adresem Czechosłowacji i Beneša. Powtarzał, że „rząd czeski ma tylko dwie możliwości: przyjęcie lub odrzucenie niemieckiej propozycji”. „W tym drugim wypadku zgniotę Czechosłowację - zawołał z wściekłością w przestrzeń”. Groził, że „jeśli Czesi nie przyjmą moich żądań do środy 28 września do drugiej po południu, 1 października wkraczam z niemiecką armią do Sudetów”. Mocarstwa zachodnie pragnęly za wszelką cenę uniknąć takiej ewentualności. W sukurs pospieszył im włoski dyktator Benito Mussolini, który skłonił Hitlera do przyjęcia propozycji pośrednictwa duce w kwestii sudeckiej. Wódz Trzeciej Rzeszy w dniu 28 września 1938 r. przed godziną dwunastą, na dwie godziny przed upływem terminu przewidzianego w ultimatum, podjął decyzję odwlekającą w czasie zbrojną konfrontację miedzy mocarstwami. „Na życzenie mego wielkiego włoskiego sprzymierzeńca przesunąłem termin niemieckiej mobilizacji o 24 godziny", chwalił się Hitler Nevillowi Hendersonowi, ambasadorowi brytyjskiemu w Berlinie. Pożoga wojenna została chwilowo zażegnana. Hitler zaś zatelefonował do Mussoliniego i podczas rozmowy zapadła brzemienna w skutki decyzja. Ustalono, że na następny dzień, tj. 29 września 1938 r. zostaną zaproszeni do Monachium premierzy Francji Edouard Daladier, Wielkiej Brytanii Neville Chamberlain oraz obaj dyktatorzy, włoski Mussolini i niemiecki Hitler. Zabrakło

15 H. Batowski, op. cit., s. 466-469. 
natomiast miejsca dla przedstawiciela Czechosłowacji, czyli państwa zagrożonego poważnymi stratami terytorialnymi $\mathrm{w}$ wyniku polityki mocarstw ${ }^{16}$.

29 września 1938 r. o godzinie 1:30 w nocy zostało podpisane w Monachium porozumienie czterech mocarstw w sprawie Sudetów. Przewidywało ono ewakuację w czterech etapach obszarów o „przewadze” niemieckiej począwszy od 1 października 1938 r., która zakończyłaby się 10 października 1938 roku. Ambasador francuski w Berlinie André François Poncet ubolewał nad losem państwowości czechosłowackiej: „kraj, który był zawsze wiernym sprzymierzeńcem [Francji], ulega znacznemu okrojeniu terytorialnemu, okropnemu poniżeniu moralnemu, odbiera mu się miasta i rejony stanowiące cenny element jego bogactwa naturalnego, musi ustępować przed groźbą ze strony silniejszego". Poncet konkludował, że Czechosłowację "poświęcono na ołtarzu pokoju”. Ambasador nie miał tyle odwagi by przyznać, że „układ monachijski był [wprawdzie] dziełem przede wszystkim angielskim", ale swoją niezbyt przyzwoitą rolę odegrała również dyplomacja francuska. Poseł czechosłowacki w Niemczech Vojtěch Mastný nie wytrzymał napięcia związanego $\mathrm{z}$ decyzjami mocarstw dotyczących nowych granic Czechosłowacji i wybuchnął płaczem. Mimo iż czechosłowacki minister spraw zagranicznych Kamil Krofta doskonale zdawał sobie sprawę z beznadziejności sytuacji, w jakiej znalazło się państwo czechosłowackie skazane „wyrokiem” mocarstw na poważne straty terytorialne, usiłował temu zaradzić, wysyłając do Monachium Mastnego oraz parlamentarnego referenta w czechosłowackim MSZ Huberta Masaříka. Jak było do przewidzenia, obaj dyplomaci nie zostali dopuszczeni obok przedstawicieli mocarstw do dyskusji na temat Czechosłowacji, czyli zostali zmuszeni do przyjęcia dyktatu w kwestii losów własnego państwa. Początkowo Beneš chciał wysłać do Monachium posła w Wielkiej Brytanii Jana Masaryka oraz posła we Francji Štefana Osuskiego. Ci jednak odmówili ze względu na "gorzkie doświadczenia” zarówno z brytyjską, jak i z francuską dyplomacją, które kazały na siebie wyczekiwać pod drzwiami gabinetu, czyli traktowały stronę czechosłowacką niepoważnie i lekceważąco. Po zapoznaniu się czeskich obserwatorów z treścią układu monachijskiego, Mastny oświadczył Chamberlainowi, że przedłoży tekst porozumienia ministrowi spraw zagranicznych oraz prezydentowi do decyzji. Usłyszał wówczas z ust premiera brytyjskiego, że żadna odpowiedź nie jest oczekiwana. Oznaczało to, że strona czechosłowacka definitywnie nie może na nic liczyć. Mocarstwa z góry wykluczyły możliwość jakiejkolwiek rzeczowej z nią dyskusji. Wszystko zostało załatwione bez udziału samej Czechosłowacji ${ }^{17}$. Państwo czechosłowackie poniosło zatem sromotną klęskę. W dużej części odpowiedzialność za to spadała na rządzącą Czechosłowacją grupę Hradu z Edvardem Benešem na czele. Oczywiście polityka Francji i Wielkiej

16 P. Schmidt, op. cit., s. 402-403, 406-407.

17 A. Francois-Poncet, Byłem ambasadorem w Berlinie. Wrzesień 1931-październik 1938, Warszawa 1968, s. 217-218, 220; Współczesna Europa..., s. 331-333; G. Ciano, Dziennik 1937-1943, Pułtusk 2006, s. 236, 237, 241; P. Drtina, Československo můj osud, svazek I, Kniha 1, Přes Mnichov do emigrace, Canada 1982, s. 178-179; V. Mastný, op. cit., s. 237-242; ČZP 1938, t. II, s. 513-517. 
Brytanii odegrała tu też swą fatalną rolę powodując, że do głosu w Europie mógł dojść wyjątkowo niebezpieczny osobnik jakim był Adolf Hitler.

\section{The collapse of the Czechoslovak state in 1938}

Edvard Beneš's responsibility for the collapse of the Czechoslovak state in 1938 raises no doubt. Beneš committed two basic errors, which disqualified him as the serious politician he pretended to be. First of all, he ignored the advice of Czechoslovak officers who treated the threat posed by Hitler's Germany with appropriate concern; and secondly, he rejected the idea of an alliance with Poland. His hatred towards the Polish state, going back to the end of WWI, had a major impact on national policies during the interwar period, even though it was undefendable from a rational point of view. Both countries, Poland and Czechoslovakia, required an ally to survive, yet this seemingly obvious truth failed to reach the minds of Czechoslovak politicians.

Poland would soon become the main victim of the tragedy of WWII, causing this country to pay the highest price and cease counting as a potential ally. Poland and Czechoslovakia fell under the protectorate of the USSR. Facing Germany's threat, Beneš counted in his naivety on support from the Soviets, thus proving his complete obliviousness to what the Soviet Union really was and what one could expect from it.

In Munich, the European powers excluded the Czechoslovak authorities beforehand from any reasonable discussion, and took all the decisions behind their backs. The Czechoslovak state suffered a crushing defeat, for which Edvard Beneš's cabinet, and himself in particular, should be held responsible for the most part. However, the passive policies of France and Great Britain ought to be blamed as well, as they allowed Adolf Hitler to come to power in Europe.

Translated by Jakub Perliński

\section{Поражение Чехословацкого государства в 1938 г.}

Ответственность Эдварда Бенеша за поражение Чехословацкого государства в 1938г. не подлежит никакому сомнению. Бенеш совершил две основные ошибки, которые дисквалифицировали его как серьезного политика, каким он хотел считаться. Во-первых, он пренебрег советами чехословацких военных, которые всерьез воспринимали угрозу, исходящую от гитлеровской Германии. Во-вторых, он не допустил союза с Польшей. Его ненависть к польскому государству, которую можно датировать концом Первой мировой войны, сыграла немаловажную роль в межвоенный период. Да и в рациональных категориях сложно было бы объяснить отношение Бенеша к Польше. Оба государства Польша и Чехословакия, нуждались в союзнике, чтобы сохраниться. Однако оказалось, что эта, казалось бы, простая истина не была в состоянии дойти до сознания чехословацких политиков.

В результате трагедии Второй мировой войны, разыгравшейся после, и прежде всего, коснувшейся Польши, страна заплатила наивысшую цену и с ней перестали считаться как с потенциальным союзником. Над Польшей и Чехословакией установил свой протекторат Советский Союз. Бенеш в своей наивности рассчитывал на поддержку советской стороны в момент угрозы от Германии. Таким образом он доказывал, что совсем не понимал, чем являлся Советский Союз и чего можно было от него ожидать.

В Мюнхене европейские державы заранее исключили возможность какой-либо деловой дискуссии с чехословацкими властями. Все было решено без участия Чехословакии. 
Чехословацкое государство потерпело позорное поражение. В значительной степени ответственность за это ложится на правящую страной группировку «Град» во главе с Эдвардом Бенешом. Конечно, политика Франции и Великобритании тоже сыграла свою роковую роль и повлекла за собой то, что в Европе смог заявить о себе Адольф Гитлер.

Перевод Агнешка Поспишыл

\section{Bibliografia}

Bajorek F., Sprawa Zaolzia w okresie kryzysu, „Tydzień Polski”, 20 XII 1980.

Batowski H., Rok 1938 - dwie agresje hitlerowskie, Poznań 1985.

Beneš E., Mnichovské dny, Paměti, Praha 1968.

Below N. von, Bytem adiutantem Hitlera 1937-45, Warszawa 1990.

Borowy T. (Oswald Guziur), Beneš a Monachium, „Przegląd Tygodniowy”, 8 I 1989.

Ciano G., Dziennik 1937-1943, Pułtusk 2006.

Dokumenty československé zahraniční politiky. Československá zahraniční politika v roce 1938, t. I, leden-30 červen 1938, Praha 2000.

Drtina P., Československo můj osud, svazek I, Kniha 1, Přes Mnichov do emigrace, Canada 1982.

Francois-Poncet A., Byłem ambasadorem w Berlinie. Wrzesień 1931-październik 1938, Warszawa 1968.

Henderson N., Nieudana misja Berlin 1937-1939, Warszawa 1970.

Kamiński M. K., Konflikt polsko-czeski 1918-1921, Warszawa 2001.

Landau Z., Tomaszewski J., Monachium 1938, Polskie dokumenty dyplomatyczne, Warszawa 1985. Majewski P. M., Edvard Beneš i kwestia niemiecka w Czechach, Warszawa 2001.

Masařík H., V proměnach Evropy. Paměti československeho díplomata, Praha 2002.

Mastný V., Vzpomínky diplomata, Ze vzpominek a dokumentů československého vyslance, Praha 1997. Mnichov v dokumentech, t. II, Zrada česke a slovenske burzuasie na československem lidu, Praha 1958. Polskie dokumenty dyplomatyczne 1938, Warszawa 2007.

Schuschnigg K., W zmaganiu z Hitlerem. Przezwyciężenie idei Anschlussu, Kraków 1978.

Studia z Najnowszych Dziejów Powszechnych, t. 3, PWN, Warszawa 1963.

Schmidt P., Statysta na dyplomatycznej scenie, Kraków 1962.

Współczesna Europa polityczna. Zbiór umów międzynarodowych 1919-1939, oprac. W. Kulski, M. Potulicki, Warszawa-Kraków 1939.

Zacharias M. J., Sytuacja międzynarodowa i polityka zagraniczna Polski w latach 1936-1939 (w związku z publikacją materiałów Juliusza Łukasiewicza pt. Dyplomata w Paryżu 19361939, red. W. Jędrzejewicz i H. Bułhak), „Kwartalnik Historyczny”, R. CIV, Warszawa 1997.

Marek Kazimierz Kamiński, prof. zw. dr hab., prof. IH PAN, historyk. Zainteresowania badawcze: najnowsza historia Polski, historia stosunków międzynarodowych po 1918 roku. Najważniejsze publikacje: Eward Beneš we współpracy z Kremlem. Polityka zagraniczna władz czechosłowackich na emigracji 1943-1945, Warszawa 2009; Wobliczu sowieckiego ekspansjonizmu. Polityka Stanów Zjednoczonych i Wielkiej Brytanii wobec Polski i Czechosłowacji 1945-1948, Warszawa 2005; Edvard Beneš kontra gen. Władysław Sikorski: polityka władz czechosłowackich na emigracji wobec rządu polskiego na uchodźstwie 1939-1943, Warszawa 2005. 